\begin{tabular}{|l|l|l||}
\hline \multicolumn{2}{|c|}{ PublisherInfo } \\
\hline \hline PublisherName & $:$ & BioMed Central \\
\hline \hline PublisherLocation & $:$ & London \\
\hline \hline PublisherImprintName & $:$ & BioMed Central \\
\hline \hline
\end{tabular}

\title{
Antisense spuds
}

\begin{tabular}{|l|l|l||}
\hline \multicolumn{2}{|c|}{ ArticleInfo } \\
\hline \hline ArticleID & $:$ & 4419 \\
\hline \hline ArticleDOI & $:$ & $10.1186 /$ gb-spotlight-20020311-01 \\
\hline \hline ArticleCitationID & $:$ & spotlight-20020311-01 \\
\hline \hline ArticleSequenceNumber & $:$ & 85 \\
\hline \hline ArticleCategory & $:$ & Research news \\
\hline ArticleFirstPage & $:$ & 1 \\
\hline \hline ArticleLastPage & $:$ & 2 \\
\hline \hline & & RegistrationDate : 2002-3-11 \\
\hline ArticleHistory & $:$ & OnlineDate \\
\hline \hline ArticleCopyright & $:$ & BioMed Central Ltd2002-11 \\
\hline \hline ArticleGrants & $:$ & \\
\hline \hline ArticleContext & $:$ & 130593311 \\
\hline \hline
\end{tabular}




\section{Jonathan B Weitzman}

Email: jonathanweitzman@hotmail.com

Unmodified starches present a problem to the frozen food industry as they tend to result in poor texture upon cycles of freeze-thawing. In the March issue of Nature Biotechnology, Jobling et al. describe a genetic solution to generating freeze-thaw-stable starch (Nature Biotechnology 2002, 20:295-299). They created potato plants with reduced levels of the three starch synthase genes using triple antisense technology. The authors showed that the there was an efficient downregulation of the three enzymes, and note that this is the first demonstration of simultaneous 'knockout' of three nonhomologous genes using antisense technology. Extracts from the amylose-deficient spuds showed remarkable resistance to repeated freeze-thawing. This genetic strategy is superior to currently used chemical modification practices.

\section{References}

1. Nature Biotechnology, [http://biotech.nature.com]

2. Specificity of starch synthase isoforms from potato. 